\title{
Professional education in PPPM as the realistic platform for the medicine of the future: EPMA takes action
}

\author{
Olga Golubnitschaja
}

From EPMA-World Congress 2013

Brussels, Belgium. 20-21 September 2013

Predictive, Preventive and Personalised Medicine (PPPM) is the new integrative concept of the paradigm change in healthcare that enables to predict individual predisposition before onset of the disease, to provide targeted preventive measures and create personalised treatment algorithms tailored to the person. The EPMA Journal (BMC, London, UK PubMed-indexed "open access", http://www.epmajournal.com/ ) overviews the whole spectrum of PPPM relevant bio/medical scientific fields, publishing both review and research articles as well as position papers focused on

$\triangleright$ patient needs

$>$ scientific and technological excellence in PPPM

$\triangleright$ professional consolidation

$>$ implementation of innovative technologies in daily medical practice.

The expected impacts for the healthcare promotion are conducive to more effective population screening, prevention early in childhood, identification of persons at-risk, stratification of patients for the optimal therapy planning, prediction and reduction of adverse drug-drug or drug-disease interactions relying on emerging technologies, such as pharmacogenetics, pathology-specific molecular patters, sub/cellular imaging, disease modelling, individual patient profiles, etc. Integrative approach by PPPM is considered as the medicine of the future. Being at the forefront of the global efforts, EPMA promotes the integrative concept of PPPM among healthcare stakeholders, governmental institutions, educators, funding bodies, patient organisations and in the public domain (http://www.youtube.com/watch?v=SOwVS2Hh0KY). However, the main challenge of the concept performance

Correspondence: olga.golubnitschaja@ukb.uni-bonn.de

Department of Radiology, Rheinische Friedrich-Wilhelms-University of Bonn, Germany

C 2014 Golubnitschaja; licensee BioMed Central Ltd. This is an Open Access article distributed under the terms of the Creative Commons Attribution License (http://creativecommons.org/licenses/by/2.0), which permits unrestricted use, distribution, and reproduction in any medium, provided the original work is properly cited. The Creative Commons Public Domain Dedication waiver (http://creativecommons.org/publicdomain/zero/1.0/) applies to the data made available in this article, unless otherwise stated. 


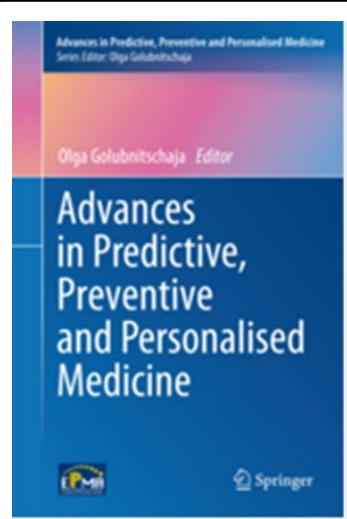

Advances in Predictive, Preventive and Personalised Medicine Series Ed.: Golubnitschaja, Olga ISSN: 2211-3495

Figure 1 Professional education in Predictive, Preventive and Personalised Medicine gets effectively promoted by the book-series "Advances in PPPM", Springer

the EPMA umbrella (http://www.youtube.com/watch? $\mathrm{v}=$ TwiUGaGashI). EPMA-YPS is keen to offer their expertise in helping young professionals, from a range of backgrounds, to identify useful international contacts, to provide support for them in applying for funding and to gain travel fellowships for research activities (EPMA-YPS Statutes, http://www.epmanet.eu/images/ stories/pdfs/EPMA-YPS\%20statutes.pdf ).

Published: 11 February 2014

doi:10.1186/1878-5085-5-S1-A12

Cite this article as: Golubnitschaja: Professional education in PPPM as

the realistic platform for the medicine of the future: EPMA takes action. EPMA Journal 2014 5(Suppl 1):A12.
Submit your next manuscript to BioMed Central and take full advantage of:

- Convenient online submission

- Thorough peer review

- No space constraints or color figure charges

- Immediate publication on acceptance

- Inclusion in PubMed, CAS, Scopus and Google Scholar

- Research which is freely available for redistribution 